Modelling methodology for estimating forage yield potential in Canada

\%. Agriculture APR $\begin{aligned} & \text { APRada } \\ & \text { Canada }\end{aligned}$

Library / Bibliothèque, Ottawa K1A 0C5

630.72

C759

C $91-6$

OOAg

c. 3 


\section{Digitized by the Internet Archive in 2013}




\title{
Modelling methodology for estimating forage yield potential in Canada
}

\author{
A. BOOTSMA and J.B. BOISVERT
}

Land Resource Research Centre

Ottawa, Ontario

Technical Bulletin 1991-6E

LRRC Contribution No. 90-50

Research Branch

Agriculture Canada

1991 
Copies of this publication are available from

Director

Land Resource Research Centre

Rescarch Branch, Agriculture Canada

Ottawa, Ontario

K1A 0C6

Produced by Research Program Service

- Minister of Supply and Services Canada 1991

Cat. No. A54-8/1991-6E

ISBN 0-662-18569-2

Eqalement disponible en français sous le titre

Mechade de madelisarion relarive d l'estimation des

potentiels de rendement des plantes fourrageres au Canada

\section{Cover illustration}

The dots on the map represent

Agriculture Canada research

establishments. 
FOREWORD

SUMMARY

LIST OF TABLES

4

LIST OF FIGURES

LIST OF APPENDICES

1. INTRODUCTION

2. MODEL DEVELOPMENT

2.1 Selection of Model 7

2.2 Simulating Growth Periods and Cutting Schedules 8

2.2.1. Criteria for estimating date of first cut 8

2.2.2. Criteria for estimating dates of addi- 10 tional cuts

2.2.3. Validation of cutting date criteria

2.3 Additional Modifications to the FAO Model for Application for Forages

2.3.1. Workability factor

2.3.2. Respiration losses

2.3.3. Leaf area index

2.3.4. Start of growing season

2.3.5 Soil moisture budgeting

2.3.6. Harvest index

2.4 Simulation of Potential Net Dry Matter Yield 16

2.4.1. Assumptions for maximum crop growth rate 16

2.4.2. Validation of potential (constraint-free) yield

2.5 Simulation of Anticipated Net Dry Matter Yield 19

2.5.1. Model procedures and modifications 19

2.5.2. Validation of anticipated yield 21

a) Alfalfa \& timothy yield validation 21

b) Wheatgrass yield validation 25

3. SUMMARY AND CONCLUSIONS 25

4. REFERENCES 28

5. APPENDIX 31 



\section{FOREWORD}

This modelling effort came about as a result of the need for forage yield information for broad scale land evaluation studies in Canada. Forages constitute a major portion of the total agricultural production system in almost all regions of the country and no evaluation of land capability and crop suitability would be complete without its consideration. Previous work has been done to estimate crop production potentials of five annual crops grown in Canada using a crop growth model. However, a suitable model for forages was not available until now.

The modelling work was undertaken as part of a land evaluation study led by $\mathrm{Dr}$. J. Dumanski in the Land Resource Research Centre. Throughout the course of this work progress was reviewed by the project team and on-going plans were formulated as required. The objective was to develop a model which would estimate forage yields for all areas of Canada using the climatic normals data available in the Land Potential Data Base, and for Agroecological Resource Areas in the prairie region using climatic normals data prepared under the Prairie Land Evaluation Project.

\section{SUMMARY}

This bulletin describes the modelling methodology that was developed to estimate average potential (constraint-free) and anticipated (rainfed) forage yields in Canada. A revised general crop growth model previously used to estimate production potentials of annual crops in Canada was selected as a basis for the forage model (FORYLD). Subroutines were developed and validated with field data to simulate normal growth periods and cutting schedules for alfalfa and for grasses (timothy, bromegrass, wheatgrass). Each growth period was then treated as a full season for annual crops in the FAO model. Several significant modifications in addition to cutting schedules were incorporated into FORYLD. These included the following: i) the manner in which leaf area index was estimated; ii) the relationship between maximum leaf photosynthesis and temperature; and $i i i)$ the proceduree used to determine the moisture stress factor for computing anticipated yields from potential yields. Comparisons of model yield estimates with yields observed in field trials at various locations across Canada were made for calibration and validation. Results indicate that the model estimates potential and anticipated yields with an accuracy of about $\pm 1 t / h a$. 


\section{LIST OF TABLES}

$\underline{\text { Page }}$

Table 1. Criteria for estimating average cutting dates for alfalfa - Option 1.

Table 2. Criteria for estimating average cutting dates for alfalfa - Option 2.

Table 3. Criteria for estimating average cutting dates for grasses.

Table 4. Correlation coefficients ( $r$ ) between estimated and observed average cutting dates for alfalfa and grasses.

Table 5. Comparison between estimated and observed average potential dry matter yields of alfalfa and timothy.

Table 6. Relationship between available water-holding capacity and soll particle size groups.

Table 7. Comparison between observed and estimated average anticipated dry matter yield ( $\mathrm{ya}_{\mathrm{a}}$ ) for alfalfa.

Table 8. Comparison between observed and estimated average anticipated dry matter yield $\left(\mathrm{B}_{\mathrm{ya}}\right)$ for timothy.

Table 9. Comparison between observed and estimated average anticipated dry matter yield $\left(\mathrm{B}_{\mathrm{ya}}\right.$ ) for crested wheatgrass.

Table 10. Comparison between observed and estimated average anticipated dry matter yield $\left(\mathrm{B}_{\mathrm{ya}}\right.$ ) for intermediate wheatgrass. 
LIST OF FIGURES

Page

Figure 1. Relative development rate (RDR) as a function of photoperiod or daylength ( $P$ ).

Figure 2. Relationship between the average mean daily air temperature and the variable DAYS used in selection of cutting date criteria for alfalfa.

Figure 3. Comparison between average estimated and observed cutting dates (Calendar day) for up to four cuts of alfalfa and two cuts for grasses.

Figure 4. Relationship between maximum leaf photosynthetic rate $(\mathrm{Pm})$ and mean daytime temperature $\left(\mathrm{T}_{\mathrm{mdt}}\right)$.

Figure 5. Relationship between the moisture stress factor (MSF) and the soil moisture deficit - surplus (SMDS).

Figure 6. Comparison between average estimated and observed anticipated dry matter yield for all cuts of alfalfa combined (two-three cuts).

\section{LIST OF APPENDICES}

Appendix 1. Observed and estimated average cutting dates used in validation of cutting date criteria for alfalfa and grasses. 


\section{INTRODUCTION}

The concept of using computer models of crop growth and yield to estimate potential crop production from information on climatic and soil resources is not new. In 1978, the Food and Agricultural Organization of the United Nations (FAO) published procedures for assessing the production potential of eleven crops in developing countries (FAO, 1978). The FAO procedures involved estimating constraint-free yield potentials from the temperature and radiation regimes and then evaluating anticlpated yield potential under rainfed conditions by taking moisture stress and other yield-reducing factors into consideration. The procedures used to quantify the effects of water stress on yield were documented by Doorenbos and Kassam (1979). The FAO procedures were subsequently adapted for estimating the production potential of five annual crops in Canada (Dumanski and Stewart, 1983; Stewart, 1983). Estimates of crop ylelds and production potential were made for 755 soll areas outlined on the Solls Map of Canada (Clayton et al., 1977) using representative climatic and soil information for each map unit. Information on solls, climate and potential crop yields, either used as input for or generated by these studies, have since become part of a computerized information base called the Land Potential Data Base (Kirkwood et al., 1989).

Up to now, studies on the production potential of Canada's land resources have focused primarily on annual crops. There is a need, however, to develop procedures for evaluating production potentials of perennial forage crops since forages are a very significant part of the agricultural production systems in Canada. Such evaluations are needed for a variety of on-going activities, such as land use planning, crop management decisions, agricultural policy development, crop insurance programs, agricultural research planning and evaluation, and so forth.

The purpose of this bulletin is to describe the modeling procedures developed for estimating forage yield potentials in Canada from climatic and solls information. The basic framework of the modeling procedures has been previously documented (Stewart, 1983) and thus w111 only be briefly summarized. Emphasis is placed on describing the modifications made to existing methodologies for forages.

Numerous species and varieties of forages are grown in Canada. To keep the modelling effort within available resources, the work concentrated on simulating yields of several of the most common legume and grass species grown, namely alfalfa, timothy (for moist regions) and crested and intermediate wheatgrass (for the drier prairie regions). These species generally also had the most data avallable from field trials at a sufficient number of locations for model callbration and validation. Emphasis was placed on estimating long term yield potential only using climatic normals data and not on predicting yields on an annual basis.

Forage yields are frequently affected by factors such as persistence of the crop and overwintering damage, particularly for alfalfa. However, lack of avallable data and resources prevented incorporation of 
these factors into the model at this stage. Consequently, efforts were concentrated towards estimating average forage yield potentials in the first few years after establishment, assuming no yleld reductions due to winterki1l. Considerable additional research and experimental data will be necessary if these factors are to be incorporated into the model.

\section{MODEL DEVELOPMENT}

\subsection{Selection of Model}

In developing a forage model for estimating average yield potentials in Canada, we choose to modify the existing FAO model adapted for Canadian conditions by Stewart (1983) (hereafter referred to simply as the FAO model). Reasons for this choice include the following: 1) computer software for the existing model was readily avallable; 2) climatic and solls information required as input to the model were also readily avallable from the Land Potential Data Base (Kirkwood et al., 1989); 3) other workers have had some success in adapting the FAO model for estimating annual yields of forages (McBride and Brown, 1984); 4) the model is capable of estimating both potential constraint-free yield with no moisture stress and anticipated yields under rainfed conditions.

The FAO model estimates the constraint-free net biomass production $\left(B_{N}\right)$ using the equation:

$$
\mathrm{B}_{\mathrm{N}}=0.36 \mathrm{~b}_{\mathrm{gm}} /\left(1 / \mathrm{N}+0.25 \mathrm{c}_{\mathrm{t}}\right)
$$

where $b_{g m}$ is the maximum rate of biomass production ( $\mathrm{Kg} \cdot \mathrm{ha}^{-1} \cdot$ day $^{-1}$ ) under full cover (leaf area index $\geq 5$ ).

\section{$\mathrm{N}$ is the growing season length (days). \\ $C_{t}$ is a maintenance respiration function which 18 dependent on mean air temperature.}

b is determined by a method of DeWit (1965), using estimates of the maximum rate of biomass production on clear and overcast days. The seasonal mean fraction of daytime when the sky is overcast is estimated from incoming global solar radiation. b is also dependent on the maximum rate of leaf photosynthesis which 18 a function of crop species and temperature. Equation (1) assumes that the cumulative potential growth follows an idealized sigmoldal growth curve under unconstrained conditions. An adjustment is made to the constraint-free net biomass production if maximum leaf area index (LAI) of the crop is $<5.0$.

The potential net dry mattter yield $\left(B_{y}\right)$ is determined by taking the harvest index $\left(\mathrm{H}_{1}\right)$ into account, $1 . e$.

$$
\mathrm{B}_{\mathrm{y}}=\mathrm{B}_{\mathrm{N}} \times \mathrm{H}_{1}
$$

where $\mathrm{H}_{1}$ is the fraction of the net biomass production that is economically useful. B is therefore the potential yield that can be harvested under conditions where water, nutrients, weeds, pests and diseases do not limit crop growth. 
Anticipated yield $\left(B_{\text {f }}\right)$ is the harvestable yield after reductions due to workability (harvest losses) and molsture stress are taken into consideration. This is determined in the FAO model as follows:

$$
\mathrm{B}_{\mathrm{ya}}=\mathrm{B}_{\mathrm{y}} \times \text { MSF } \mathrm{x} \text { WF }
$$

where MSF is the molsture stress factor and WF is the workab111ty factor.

In the FAO model, the molsture stress factor is computed from the ratio of actual ( $A E$ ) to potential (PE) evapotranspiration, using an empirically-derived yield response factor $\left(R_{y}\right)$ taken from Doorenbos and Kassam (1979), 1.e.

$$
M S F=1-K_{y}(1-A E / P E)
$$

$A E$ and $P E$ are seasonal averages determined using a soll moisture budgeting procedure. The workablilty parameter was estimated from fall workday probabilities. Subsequent discussion will focus on the modification made to the FAO model for forages. For convenience, the modified forage model will be referred to as FORYLD.

\subsection{Simulating Growth Periods and Cutting Schedules}

The FAO model for Canada was designed to estimate average potential yields for annual crops for an average growing season whose length was determined by temperature. In the case of forages, several growth perlods and harvests are usually possible during a growing season. Therefore, subroutines were developed to simulate average growth periods and harvest dates from climatic normals data for legumes (alfalfa) and for grasses (timothy, wheatgrass). Each growth period was then treated as a complete growing season in FORYLD.

\subsubsection{Criteria for estimating date of first cut}

Average dates of first cut for both legumes and grasses were est1mated using accumulated photothermal units (PTU's). PTU's were defined as accumulated growing-degree days above a $5^{\circ} \mathrm{C}$ base (GDD) modified by a daylength factor. Previous studies have shown that accumulated GDD can be used to estimate maturity dates in specific geographic regions (Bootsma, 1984; Harcourt, 1984). However, on a Canada-wide basis, significant differences in daylength can occur which may affect the rate of development to maturity of some forage species. A review of the 11terature indicated that the effects of daylength on the rate of deve1opment can vary considerably among different forage species and varieties. However, for many of the most common grass and legume species (e.g - timothy, bromegrass, alfalfa, clover) longer daylengths induce earlier heading or flowering, while short daylengths delay flowering and may even inhibit it completely (Evans and Allard, 1934; Allard and Evans, 1941; Evans and Wils1e, 1946; Ludwig et al., 1953; DeRuiter and Taylor, 1979). Based on this evidence, an empirical approach was adopted for including daylength effects in FORYLD, using the concept of 
a relative development rate (RDR). The relationship assumed between RDR and daylength or photoperiod (P) is shown in Fig. 1 and can be mathematically approximated by

$$
R D R=-0.37+0.1626(P)-0.005942\left(P^{2}\right)+0.000062217\left(P^{3}\right)
$$

Daily PTU's were computed from GDD multiplied by RDR as follows:

$$
\text { Da1ly PTU }=\left(T_{M N}-5.0\right) \times R D R
$$

where $T_{M N}$ is the 30-year normal dally mean temperature (1951-80 period).

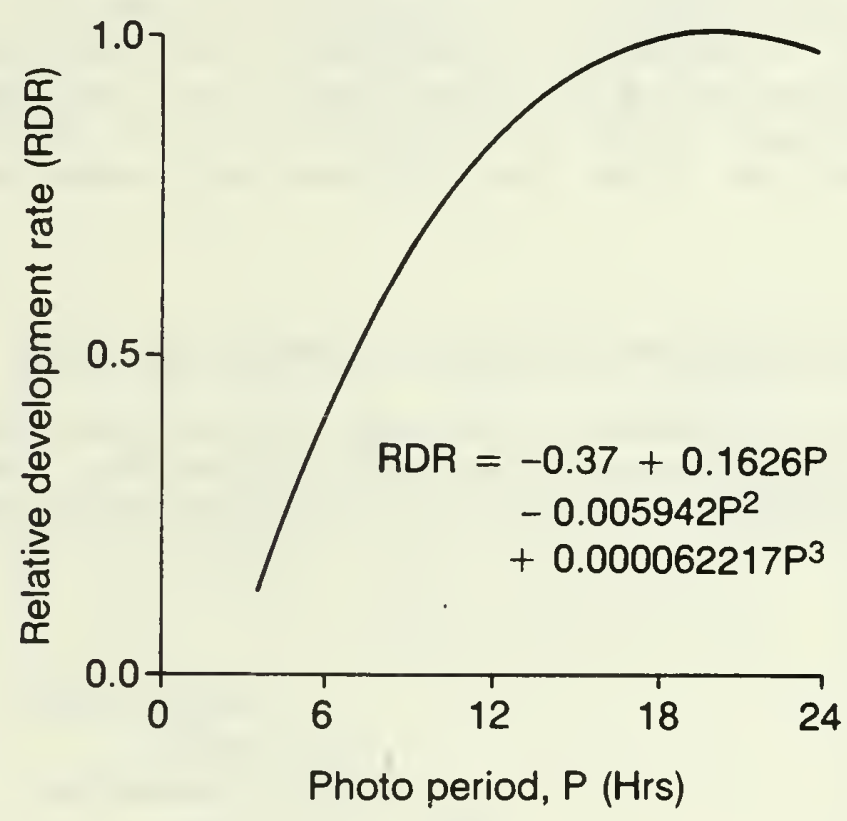

Figure 1. Relative development rate (RDR) as a function of photoperiod or daylength $(P)$.

The PTU's required for first cut were evaluated by accumulating average daily PTU's (using 1951-80 temperature normals) from the time $\mathrm{T}_{\mathrm{MN}} \geq 5^{\circ} \mathrm{C}$ in spring to the average date of first cut of alfalfa at 26 locations across Canada. Average cutting dates were determined from reports on forage variety trials conducted by various co-operators in western Canada, Ontario and the Atlantic provinces (e.g. Ontario Forage Crops Committee, 1968; Atlantic Committee on Crops, 1982; Expert Committee on Forage Crops, 1983). Observed average cutting dates were based on the data from these regional reports; available data ranged from as little as two years to more than ten years. Using this procedure, it was determined that alfalfa requires approximately 480 PTU's to reach maturity for first cut. It was assumed that regional trials were harvested around the time when early to medium maturing varieties of alfalfa reach early bloom stage. Some cultivars could require more or less than 480 PTU's for first cut, but these variations were not taken into consideration in FORYLD. Since alfalfa is often grown with timothy or bromegrass, it was assumed that the same PTU accumulation applied to grass species. 
A variety of RDR functions, similar to that of Fig. 1, which assumed either a greater or lesser effect of photoperiod on RDR, were also tried (including a constant RDR of 1.0, in which case PTU's equal GDD's). The results indicated, reasonable estimates could be made with various functions including GDD's and that, therefore, selection was not critical. However, the function shown in Fig. 1 was chosen since it resulted in the lowest standard deviation (3-4 days) of the difference between average estimated and observed cutting dates at the 26 locations.

Latitudes of locations used in these cutting date tests ranged from as far south as Ridgetown, Ontario $\left(42^{\circ} \mathrm{N}\right)$ to as far north as Fort Vermilion, Alberta $\left(58^{\circ} \mathrm{N}\right)$. This provided considerable range in daylengths ( 15 versus 18 hours, respectively, on June 25). The influence of time of year on daylength is also taken into consideration using the PTU concept. Locations with late springs due to cool temperatures will generally experience longer daylengths during the first growth period than other locations at the same latitude which warm up earlier in the spring.

\subsubsection{Criteria for estimating dates of additional cuts}

Criteria for scheduling additional cuts were developed from available data on cutting dates from regional variety trials of alfalfa, timothy and bromegrass. For alfalfa, cutting dates depend primarily on

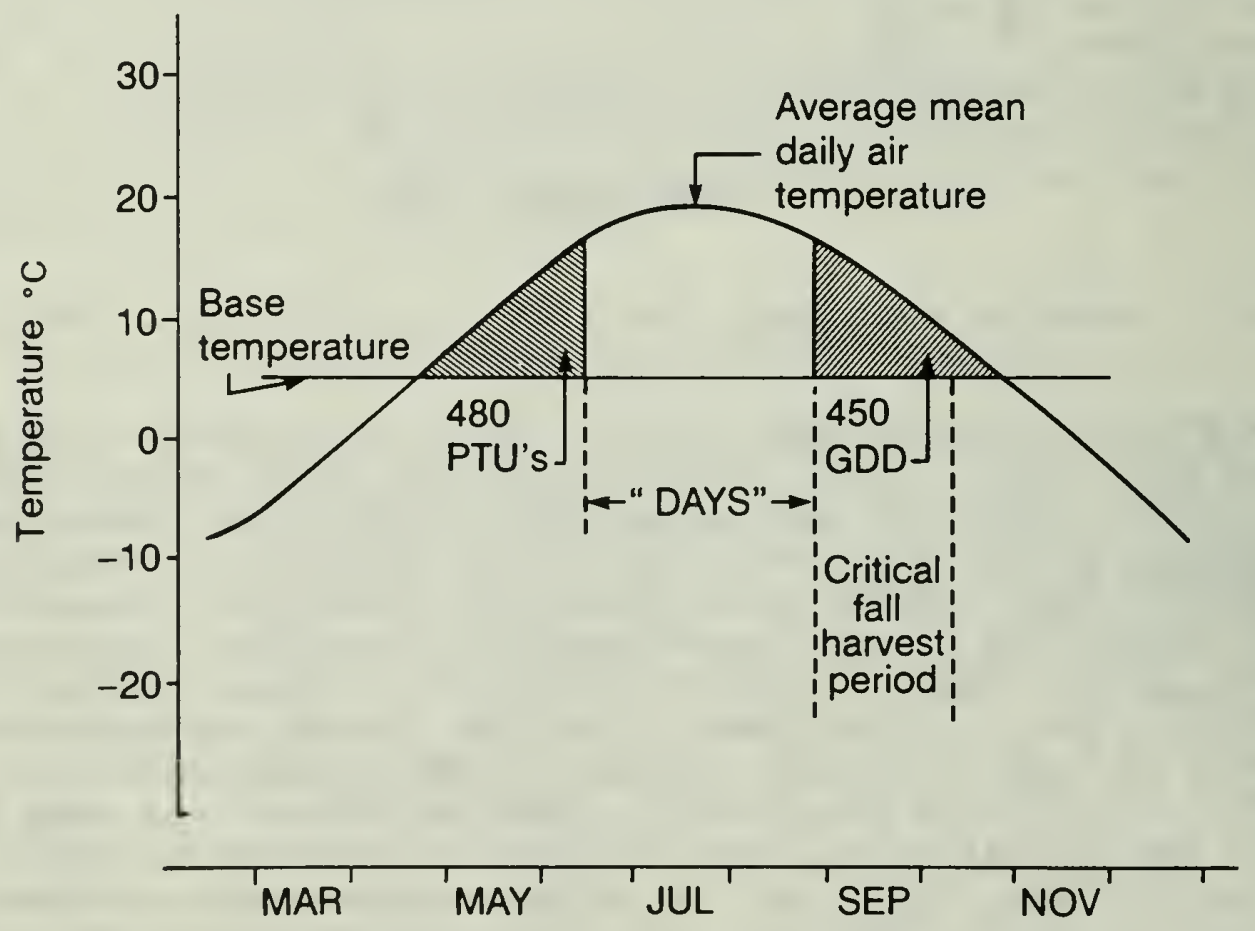

Figure 2. Relationship between the average mean daily air temperature and the variable DAYS used in selection of cutting date criteria for alfalfa. 


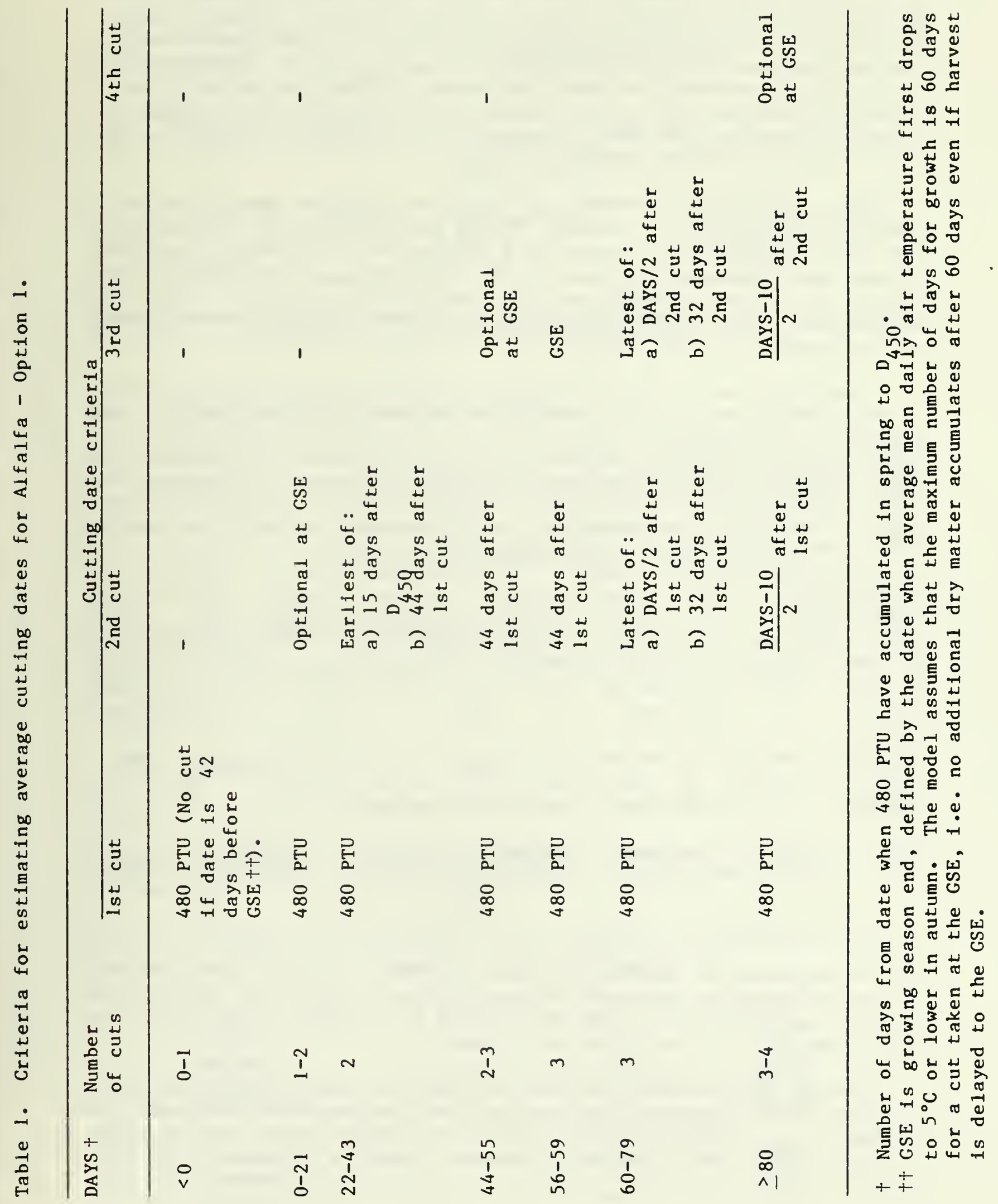


the number of days (DAYS) between the first cut and the start of the critical fall harvest period $\left(D_{450}\right)$ as shown in Fig. 2. Normally alfalfa should not be harvested during the critical 4-6 weeks period before killing frost, so that sufficient food reserves can be accumulated in the roots to decrease the chance of winter injury (Woolley and Wilsie, 1961; Fulkerson, 1970). The start of the critical fall period was estimated from the time when an average of 450 GDD still remained in the fall (Bootsma and Suzuki, 1985).

The need to avold harvesting during the critical period is still somewhat controversial. Cutting during this period may be relatively safe if winterkill is not usualiy a problem or if harvesting frequency is not too intense. Experimental data at Kamloops, B.C. (Stout, 1986) suggest that allowing sufficient time between cuts is more crucial for maintaining a healthy stand than avolding harvest during the traditional critical period for that region.

Since different cutting strategles can of ten be employed for alfalfa with similar success, two sets of cutting date criteria (Option 1 and Option 2) were developed (Tables 1 and 2). Option 1 contains the main criteria used in FORYLD. However, for selected values of the variables DAYS, a second cutting option is also applied (Table 2). If the last

Table 2. Criteria for estimating average cutting dates for alfalfa Option 2 (only if different from Option 1).

\begin{tabular}{|c|c|c|c|}
\hline \multirow{2}{*}{ DAYS } & \multirow{2}{*}{$\begin{array}{l}\text { No. of } \\
\text { cuts }\end{array}$} & \multicolumn{2}{|r|}{ Cutting date criteria } \\
\hline & & lst cut & 2nd cut \\
\hline
\end{tabular}

$\begin{array}{ccccc}22-29 & 2 & 480 \text { PTU } & \text { GSE } & - \\ 35-43 & 2-3 & 480 \text { PTU } & D_{450} & \text { Optional at GSE } \\ 60-79 & 3 & 480 \text { PTU } & 55 \text { days after lst cut } & \text { GSE } \\ 280 & 3 & 480 \text { PTU } & \frac{\text { DAYS }+5}{2} \text { days after } & \frac{\text { DAYS }+5}{2} \text { days after } \\ & & & & \text { lst cut }\end{array}$

cut is optional, it implies that this cut can be safely harvested only if winter injury is not a significant problem. If winter injury is a concern, improved survival may be achieved by leaving the fall growth to help catch snow for additional protection.

Cutting date criteria for grasses (Table 3 ) are based on the number of days (GDAYS) between first cut and the time when 400 GDD remain in the fall $\left(D_{400}\right)$. Since grasses are more winterhardy than alfalfa, there is less concern about avoiding harvest during a critical fall rest period. 
Table 3. Criteria for estimating average cutting dates for grasses.

\begin{tabular}{lllll}
\hline GDAYS ${ }^{\text {No. of }}$\begin{tabular}{c} 
cuts \\
\cline { 3 - 5 }
\end{tabular} & 1st cut & 2nd cut & 3rd cut \\
\hline 25 & $0-2$ & 480 PTU* & $\begin{array}{l}\text { Optional } 55 \text { days } \\
\text { after 1st cut* }\end{array}$ \\
$\geq 25$ & $2-3$ & 480 PTU & $\begin{array}{l}55 \text { days after } \\
\text { lst cut }\end{array}$ & $\begin{array}{l}\text { Optional } 55 \text { days } \\
\text { after 2nd cut* }\end{array}$
\end{tabular}

+ No. of days from date when 480 PTU have accumulated in spring to $D_{400^{\circ}}$

* Cut is not possible if date is < 30 days before GSE.

\subsubsection{Validation of cutting date criteria}

Cutting date criteria for alfalfa and grasses (timothy, bromegrass and wheatgrass) were validated by comparing estimated average dates based on criteria in Table 1 and 3 with observed average cutting dates at various locations (Appendix 1). Observed data were obtained from three sources: a) variety performance trials conducted across Canada (e.g. Ontario Forage Crops Committee, 1968; Atlantic Committee on Crops, 1982; Expert Committee on Forage Crops, 1983); b) Agriculture Canada, LRRC CANSIS performance management file (Dr. K.B. MacDonald, personal commun.); c) various scientific papers in the literature. Much of the data from regional performance trials were also used in developing the criteria, and thus, this validation is not strictly independent.

Estimated and observed average cutting dates were highly correlated $(r \geq 0.83)$ for each of three cuts of alfalfa and the first cut of grass (Table 4). Lower correlation for the second cut of grass was expected

Table 4. Correlation coefficient ( $r$ ) between cases of estimated and observed average cutting dates for alfalfa and grasses.

\begin{tabular}{lccc}
\hline Crop & $\begin{array}{c}\text { Cut } \\
\text { number }\end{array}$ & $\begin{array}{c}\text { Number } \\
\text { of cases }\end{array}$ & r \\
\hline Alfalfa & 1 & 44 & 0.92 \\
Alfalfa & 2 & 28 & 0.95 \\
Alfalfa & 3 & 8 & 0.98 \\
Alfalfa & $1-4$ & 81 & 0.99 \\
Grasses & 1 & 16 & 0.83 \\
Grasses & 2 & 10 & 0.41 \\
Grasses & $1-2$ & 26 & 0.96
\end{tabular}


since the critical fall harvest period is not normally important for winter-hardy grasses, thus allowing for more flexibility in harvest management. Correlation coefficients for all cuts combined were very high $(r \geq 0.96)$ since cutting dates are also correlated with time.

The linear relationships between estimated and observed average cutting dates are shown graphically in Fig. 3. These tests indicate that cutting date criteria in Tables 1 and 3 are generally suitable for

ALFALFA

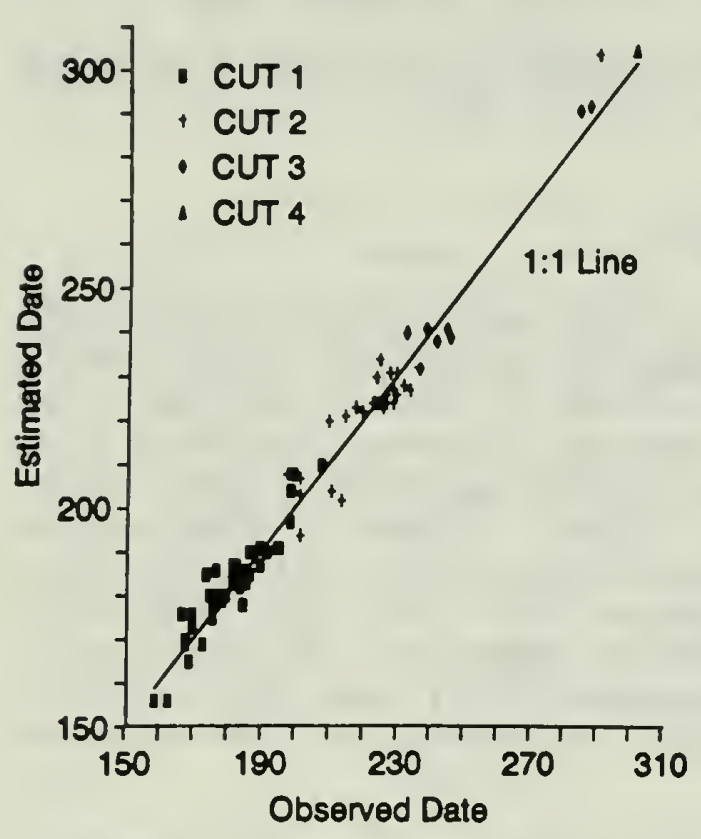

GRASS

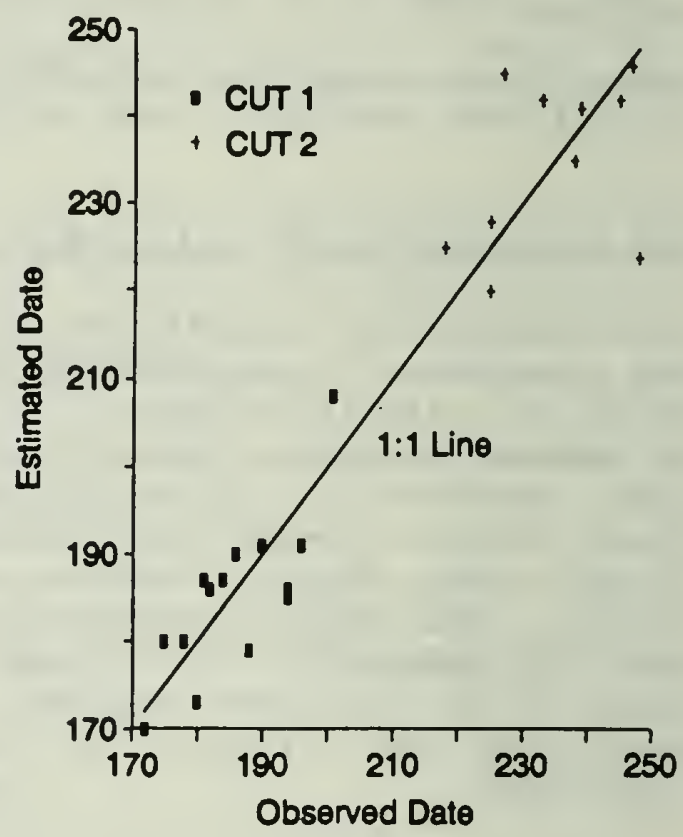

Figure 3. Comparison between average estimated and observed cutting dates (Calender day) for up to four cuts of alfalfa and two cuts for grasses.

alfalfa and grasses. However, this is not a rigorous validation since: a) some observed average cutting dates are based on relatively few years of data; b) stage of maturity at cutting was often not recorded and could vary and c) climatic stations used may. not always represent the test location adequately.

Insufficient data were available to statistically validate Option 2 (Table 2). However, enough cases suggested this option to be a valid alternative cutting strategy under some conditions. 


\subsection{Additional Modifications to the FAO Model for Application for Forages}

\subsubsection{Workability factor}

Adequate information was not available to estimate harvest losses for forages for inclusion in FORYLD. The workability factor in the FAO model (Stewart, 1983) was based on soll moisture during the fall harvest period. However, harvest losses in forages depend more on above ground conditions (precipitation and evaporation) than on moisture in the soil. Thus, this factor was set equal to 1.0 .

\subsubsection{Respiration losses}

The maintenance respiration function $C_{t}$ in equation ( 1 ) is computed in the FAO model by the expression

$$
C_{t}=C_{30}\left(0.044+0.0019 T+0.0010 T^{2}\right)
$$

where $\mathrm{C}_{30}$ is the maintenance respiration coefficient at $30^{\circ} \mathrm{C}$ and $\mathrm{T}$ is the mean air temperature over the growing season. FORYLD assumed values of 0.0283 and 0.0108 for $C_{30}$ for alfalfa and grasses, respectively (i.e. the values used for legume and non-legume crops in the FAO mode1).

\subsubsection{Leaf area index (LAI)}

The maximum crop growth rate in the FAO model was adjusted when maximum LAI was < 5.0 (Stewart, 1983). This directly affected the constraint-free net biomass production $\left(B_{N}\right)$ in equation 1 . LAI was also used to split total evaporation between bare soll evaporation and plant transpiration. In the FAO model, daily LAI values were simulated from the progression in growing season length from LAI curves for annual crops. However, these curves were found to underestimate the typical LAI for perennial forages reported in the literature (Hunt et al., 1970; Carter and Sheaffer, 1983). The procedures used to estimate LAI in FORYLD for alfalfa were based on typical LAI curves reported in the 1iterature. Maximum LAI was assumed to be 6.5 for the first cut and 6.0 for the second and third cut. If the last cut occured at the end of the growing season, a maximum LAI of 4.5 was assumed. Maximum LAI is only reached after a growth period of $\geq 45$ days. For growing periods (GSL) of $<45$ days, the LAI is estimated by the formula

$$
\text { LAI }=\text { Maximum LAI } \times \frac{\text { GSL }}{\text { Maximum GSL }}
$$

where the maximum LAI is as noted above and the maximum GSL is 45 days.

For grasses, maximum LAI was assumed to be 6.0 for the first cut and 4.0 for any additional cuts. Maximum GSL was set at 55 days. 


\subsubsection{Start of growing season}

The FAO model assumed the start of the growing season for annual crops as the day on which the average dally minimum alr temperature exceeded $5^{\circ} \mathrm{C}$ (Stewart, 1983). The growlng season for perennial forages is longer; in FORYLD it was assumed to colncide with the period when the average dally mean alr temperature $\left(\mathrm{T}_{\mathrm{MN}}\right.$ ) exceeded $5^{\circ} \mathrm{C}$ (Chapman and Brown, 1966). The first growth period began at the start of the growing season and ended when the first cut was taken. Growth periods for later cuts began the first day following the previous cut and ended on the cutting date.

\subsubsection{So11 mo1sture budget1ng}

In FORYLD soll water budgeting was initiated in spring (known as the Molsture Growing Season Start, or MGSS) (Stewart, 1983) when the average dally potential evapotranspiration (PE) first exceeded average dally precipitation $(P)$ or on the first date when $T_{M N}$ exceeded $5.0^{\circ} \mathrm{C}$, whichever occured last. The latter date corresponded closely to the time when average snow depth was less than $2.5 \mathrm{~cm}$ for seven consecutive days as reported in the Hydrological Atlas of Canada (Fisheries and Environment Canada, 1978). Thus, it was assumed that the soil surface had thawed, and evaporation proceeded normally after this date.

\subsubsection{Harvest 1 ndex}

A harvest index $\left(\mathrm{H}_{f}\right)$ of 0.95 was assumed for FORYLD, meaning that almost all of the net blomass production was available for harvest. A small portion $(5 \%)$ was assumed as unharvested stubble and wastage.

\subsection{Simulation of Potential Net Dry Matter Y1eld}

\subsubsection{Assumptions for maximum crop growth rate}

Constraint-free net blomass production $\left(B_{N}\right)$ is a function of $b$, the maximum rate of gross biomass production ( $\mathrm{N}$. (1)). b is in tom affected by the rate of biomass production on clear and gimercast days and the fraction of the day that the sky is overcast (Stewart, 1983). $b_{\text {gm }}$ is further adjusted depending on the maximum leaf photosynthesis r要要e $\left(P_{m}\right)$, which is a function of the seasonal mean daytime temperature ( $T_{\text {mdt }}$ ) and the crop species. McBride and Brown (1984) callbrated $P$ versus $I_{\text {mdt }}$ curves for six forage species (all $\mathrm{C}_{3}$ crops) using yield data from forage variety trials in Ontario. Curves for medium maturing alfalfa and for timothy were selected from McBride and Brown (1984) for use in FORYLD as follows:

for alfalfa,

$$
P_{m}=-57.6446+8.2645 T_{m d t}-0.2066\left(T_{m d t}\right)^{2}
$$


for grasses,

$$
\mathrm{P}_{\mathrm{m}}=3.0667 \mathrm{~T}_{\mathrm{mdt}}-0.1022\left(\mathrm{~T}_{\mathrm{mdt}}\right)^{2}
$$

These relationships are compared with the $\mathrm{P}_{\mathrm{m}}$ versus $\mathrm{T}_{\mathrm{mdt}}$ curve used for $\mathrm{C}_{3}$ crops in the FAO model (Fig. 4).

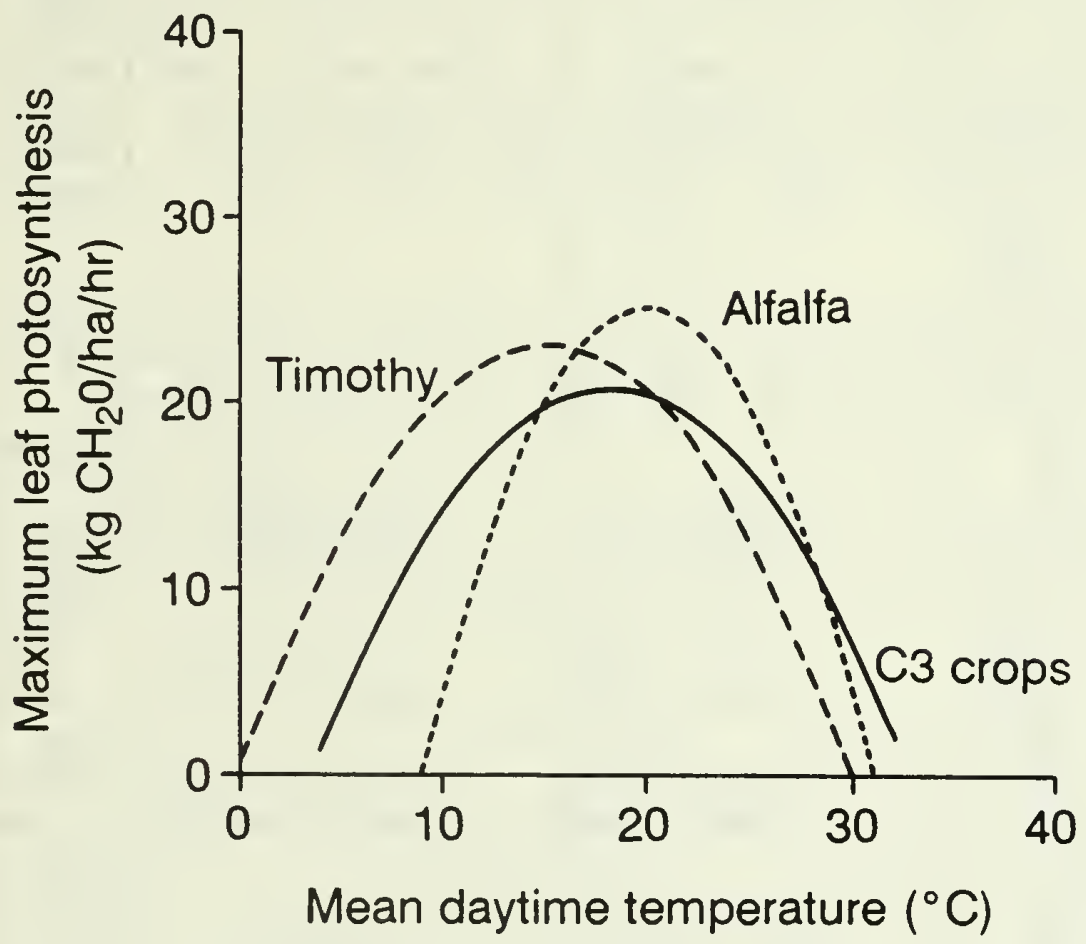

Figure 4. Relationship between maximum leaf photosynthetic rate (Pm) and mean daytime temperature $\left(\mathrm{T}_{\mathrm{mdt}}\right)$.

\subsubsection{Validation of potential (constraint-free) yield}

Estimates of potential forage yields with no moisture stress (B , eq. (2)) were compared with observed yields from regional variety petformance trials for selected locations in Canada (Table 5). Several years with the highest yields were selected, assuming that there would be little or no moisture stress in these years. However, since some stress due to moisture deficits may occur even in the best years, the observed yields are themselves only estimate of potential yield. Management factors such as fertilizer applications and harvest dates may also have influenced observed yields. In western Canada, observed yields were extracted from data on irrigated trials. A yield was determined for each trial-year by averaging data for selected standard varieties. Effects of age of stand on yields was minimized by using data only from the first three years after establishment. 


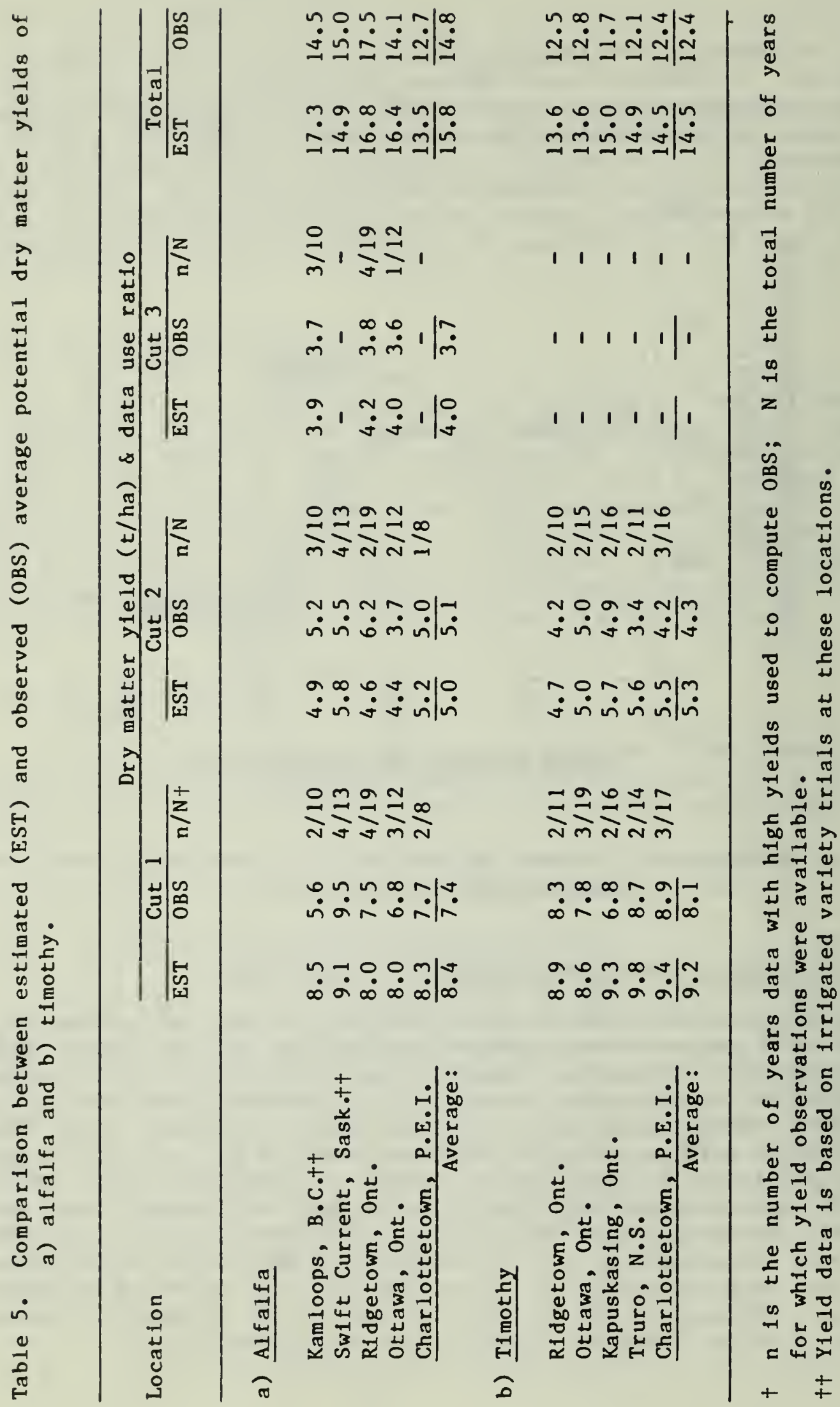


Potential dry matter yields estimated by FORYLD were, on average, about $1 \mathrm{t} / \mathrm{ha}$ higher than observed yields (Table 5). At several individual locations, the estimated yields were almost $3 \mathrm{t} / \mathrm{ha}$ above observed values (e.g. alfalfa cut 1 at Kamloops; timothy cut 1 at Kapuskasing). Low observed yields at these locations are most likely due to below optimum management levels or due to moisture stress. In several instances model estimates were lower than observed yields (e.g. alfalfa cut 2 at Ridgetown). This could be due to differences in length of growing period used in the model in comparison to the field trial or because of better than average temperature and/or solar radiation during a growth period. However, since model estimates were based on long term normals, reasons for yield differences could not be positively identified.

Estimated potential dry matter yields were compared with observed values for a number of additional locations not shown in Table 5 . In most cases, observed yields were lower than estimated values. Largest differences were experienced for the first cut of alfalfa, where observed potential yields were typically 2 to $3 \mathrm{t} / \mathrm{ha}$ lower. It is likely that even in the best years, forages grown in regional performance trials do not always reach the maximum potential yield due to below optimum management levels (i.e. fertility), moisture stress and/or winter injury.

Overall, the model seems to provide reasonable estimates of the potential constraint-free yield of forages. The comparative tests are only a general indicator and not a rigorous validation of the model. Differences in estimated potential yields between locations for individual cuts (Table 5) are relatively small. This may be expected, since potential yields are only affected by temperature, solar radiation and length of growing period and not by moisture supply. The number of cuts that are feasible is the greatest factor affecting the potential yield of forages at a given location.

\subsection{Simulation of Anticipated Dry Matter Yields}

\subsubsection{Model procedures and modifications}

The modified FAO model estimates anticipated dry matter yields $\left(B_{1}\right)$ by reducing potential yields $\left(B_{y}\right)$ by a moisture stress factor (MSF) computed from the AE/PE ratio (Section 2.1, eq. (3) and (4)). Estimated yields using the FAO procedure to compute the MSF were compared with average observed yields from regional variety performance trials at sixteen locations across Canada for the first two cuts of alfalfa and nine locations for two cuts of timothy. The yield response factory $\mathrm{K}_{\mathrm{y}}$ was assumed to be 1.0 and 1.1 for alfalfa and timothy respectively. Soil available water-holding capacity (AWC) was estimated from soil particle size information obtained from trial reports or directly from co-operators. The relationship between particle size and AWC was taken from DeJong and Shields (1988) and is shown in Table 6.

Applying these relationships directly to the modified FAO model gave unsatisfactory results. On the average, forage yields were overestimated by about $70 \%$ and $26 \%$ respectively for the first two cuts of 
Table 6. Relationship between available water-holding capacity and soil particle size group (from DeJong and Shield, 1988).

\begin{tabular}{cl}
$\begin{array}{c}\text { Available } \\
\text { water-holding } \\
\text { capacity (mm) }\end{array}$ & \multicolumn{1}{c}{$\begin{array}{c}\text { Soil particle } \\
\text { size groups }\end{array}$} \\
\hline 50 & Sand; loamy sand \\
100 & Sandy loam \\
150 & Very fine sandy loam; clay \\
200 & Silt loam; sandy clay; clay loam \\
250 & Silty clay loam; sandy clay; \\
& /silty clay; clay; heavy clay
\end{tabular}

alfalfa, and by about $40 \%$ and $70 \%$, respectively, for the first two cuts in timothy. Estimates were relatively insensitive to changes in $\mathrm{K}_{\mathrm{y}}$ and AWC, and thus, could not be readily improved by adjusting these parameters. For these reasons, a different procedure was used to compute the MSF.

The approach adopted was that of McBride and Brown (1984), in which the MSF is related to a parameter known as the soil moisture deficitsurplus (SMDS). The SMDS is computed as follows:

$$
\operatorname{SMDS}=P+\theta_{i}-P E
$$

where $P$ is the total precipitation during the growth period. $\theta_{1}$ is the plant-available soil water content at the start of the
growth period.

and PE is the total potential evapotranspiration during the growth period.

McBride and Brown (1984) calibrated the relationship between MSF and SMDS using annual forage yield data from variety performance trials in Ontario. However, because of much drier conditions on the prairies, recalibration of the MSF versus SMDS curve was necessary and this was accomplished by plotting actual MSF versus SMDS for all available locations with alfalfa and timothy yield data.' A hand-fitted curve was drawn through the higher MSF values (low MSF values were assumed to be due to below optimum management or poor stand persistence). Actual MSF values were determined by:

$$
\text { MSF }=\frac{{ }_{a}}{B_{y}}
$$



where ${ }_{\text {a }}$ is the average dry matter yield observed for all avallable
years in regional variety performance trials. By is the constraint-free (potential) net dry matter yield
estimated by FORYLD.

The relationship between MSF and SMDS used in FORYLD is shown in Figure 5 and is presented by the following cubic polynomial equation:

$$
M S F=0.594+2.426 \text { SMDS }-1.423(\text { SMDS })^{2}-7.905(\text { SMDS })^{3}
$$

where SMDS is in metres. This estimate of MSF was then used in the calculations of anticipated dry matter yield ( $\left.{ }_{y a}\right)$.

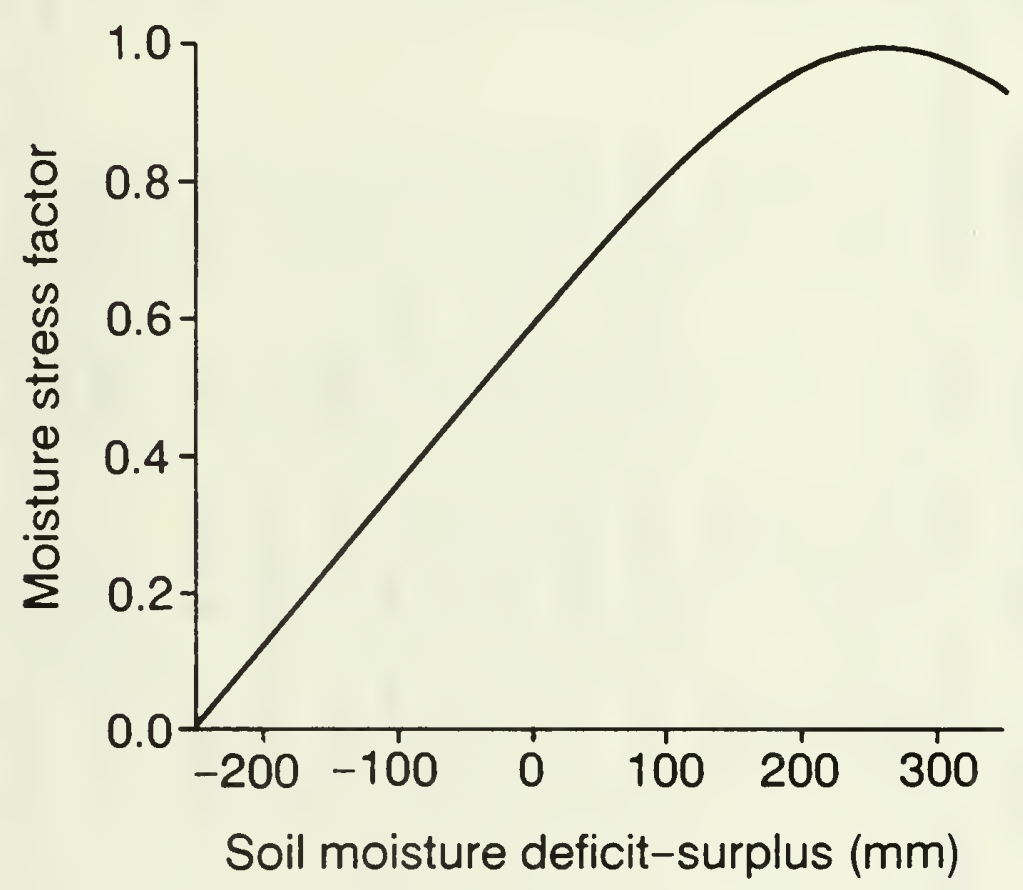

Figure 5. Relationship between the moisture stress factor (MSF) and the soil moisture deficit - surplus (SMDS).

As in the case of McBride and Brown (1984), this relationship was found to be equally valid for both alfalfa and timothy, and applicable for all cuts.

\subsubsection{Validation of anticipated dry matter yield ( $\left.{ }_{y a}\right)$}

a) Alfalfa and timothy yield validation

Model estimates were compared with average observed yields at selected locations across Canada for up to three cuts of alfalfa (Table 7) and two cuts of timothy (Table 8 ), in order to validate as 


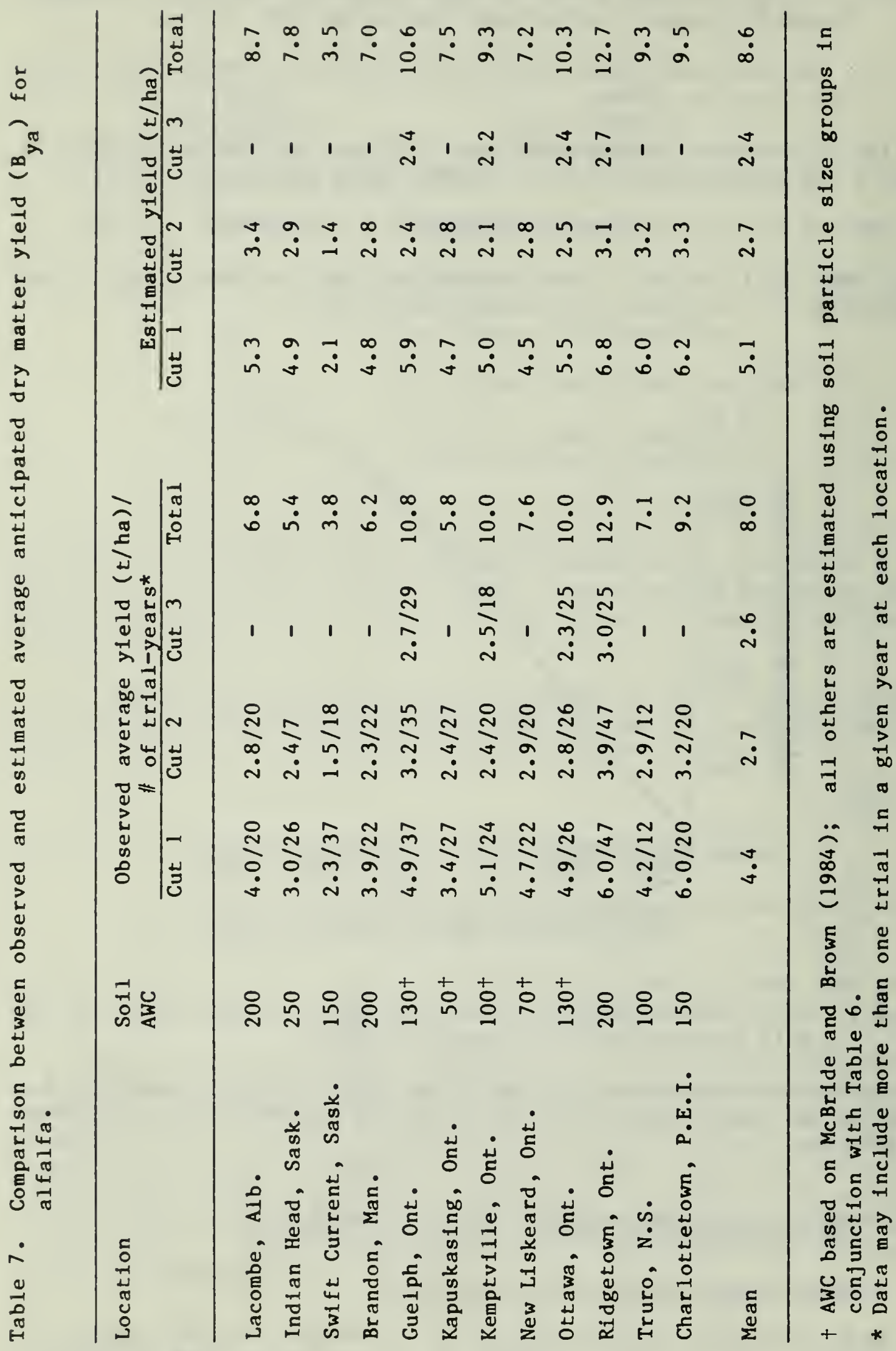




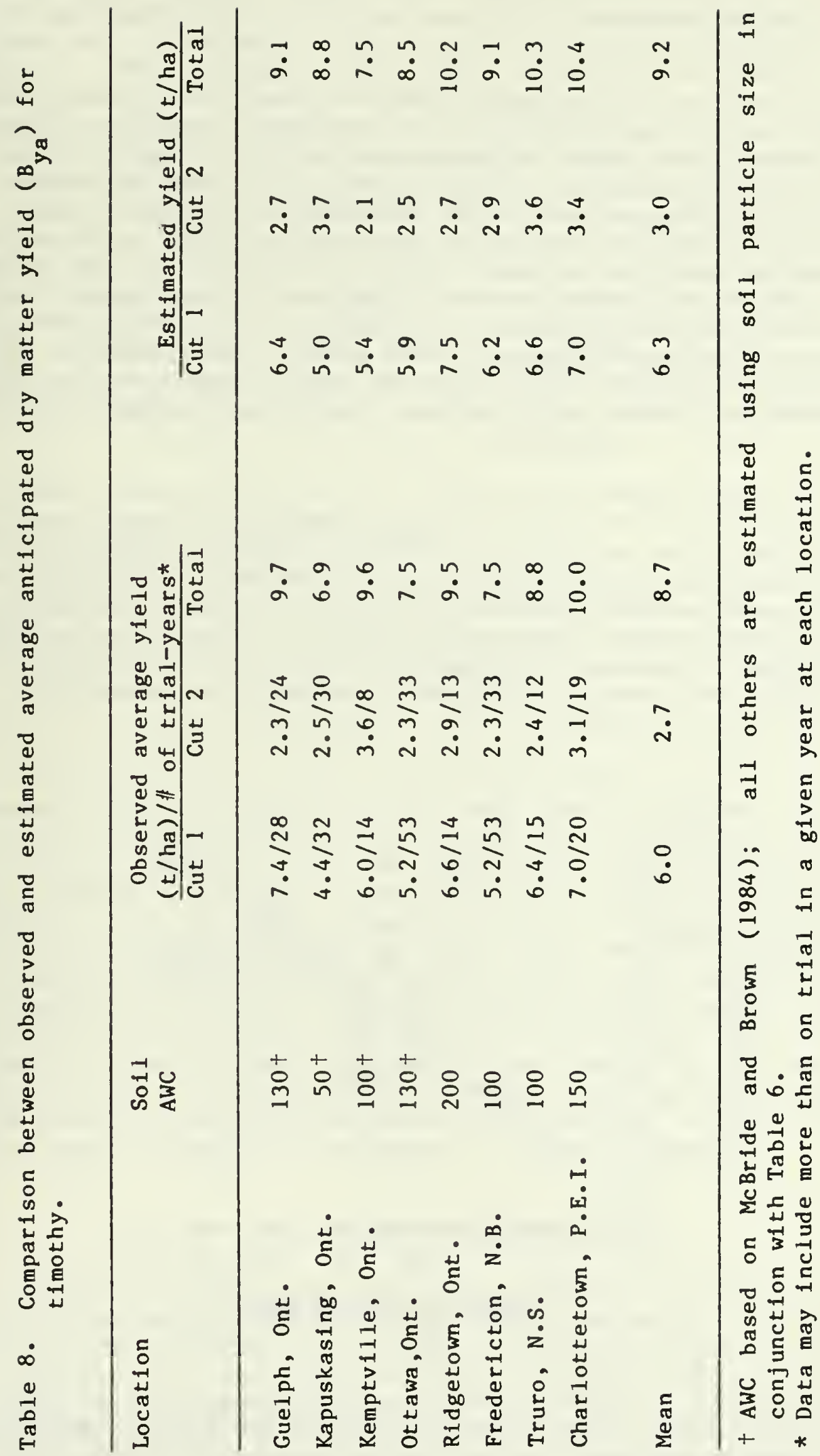


much as possible anticipated dry matter yleld estimates produced by FORYLD. Observed average yields were calculated by averaging annual yields observed in forage variety trials conducted in the various regions of Canada (e.g. Ontario Forage Crops Committee, 1968; Atlantic Committee on Crops, 1982; Expert Committee on Forage Crops, 1983). Only yields based on data from the first and second year after the year of establishment were used to compute an average. Thus, effects of decline in stand persistence and of winter injury were minimized. In cases where significant winter infury was noted with trial results, the yields were omitted from the averaging procedure. The source of soll AWC information used in estimating $B$ is indicated in the tables. AWC's were either estimated from soll particle size information for the trial location used in conjunction with Table 6 , or they were taken from estimates provided by McBride and Brown (1984). The number of trialyears of regional variety trial data from which observed average yields were computed are shown in the tables. Some years contain data from more than one trial at a location.

Mean estimated yields for alfalfa for all cuts combined were only $0.6 \mathrm{t} / \mathrm{ha}$ higher than the mean observed average for twelve locations (Table 7). There was a good correlation $(r=0.91$ ) between estimated and observed alfalfa yields for all cuts combined at individual locations and the values followed closely to the $1: 1$ relationship (Fig. 6 ). For timothy, mean average estimated yleld for all locations was within $0.3 t /$ ha of mean observed yields for both cuts 1 and 2 (Table 8 ). At some locations, estimated yields exceeded the observed by more than

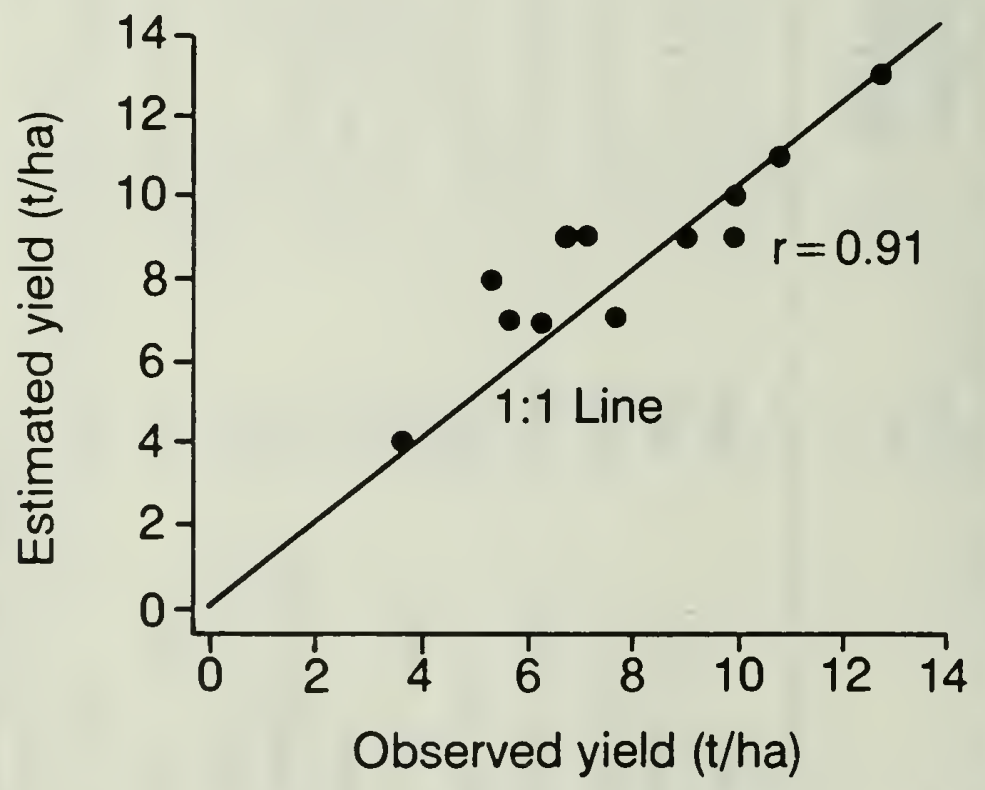

F1gure 6. Comparison between average estimated and observed anticipated dry matter yield for all cuts of alfalfa combined (two-three cuts). 
$1 \mathrm{t} /$ ha (e.g. first cut alfalfa at Indian Head, Kapuskasing and Truro; first cut timothy at Fredericton, second cut at Kapuskasing, Kemptville and Truro).

Some large differences between estimated and observed yields may be expected for several reasons: (i) soil AWC is only an approximate estimate; in many cases estimated yields would coincide with observed values if the AWC was adjusted by only one category (50 mm) or less; (ii) weather conditions during the trial years may have differed significantly from normal, particularly if relatively few years' data were avallable; and (iii) observed yields may have been influenced by management level, stand persistence, winter survival and varietal differences. While these tests do not provide a rigorous validation of the model, they do indicate that FORYLD provides reasonable estimates of both alfalfa and timothy yields under rainfed conditions. Although no specific comparisons were made with bromegrass yields, cutting schedules and yields are expected to be similar to timothy.

\section{b) Wheatgrass yield validation}

Observed yields on crested and intermediate wheatgrass were extracted and averaged from regional trial reports in western Canada (e.g. Expert Committee on Forage Crops, 1983). Data for the first three years only after the year of establishment were used. Comparisons between observed yields and those estimated for grasses by FORYLD are shown in Table 9 for crested and Table 10 for intermediate wheatgrass.

Estimated yields assume a soil AWC of $200 \mathrm{~mm}$ unless soil textural information was available, in which case, Table 6 was used to determine the AWC. Estimated mean yields averaged for all locations were within $0.1 \mathrm{t} / \mathrm{ha}$ of observed yields for both crested and intermediate wheatgrass. However, differences between observed and estimated yields for individual locations were frequently $0.5 \mathrm{t} / \mathrm{ha}$ or more. These differences may be expected since soil AWC values are very approximate and since observed yields are often based on only a few years' data. As was the case with alfalfa and timothy, yield estimates would coincide with observed values in most cases with an adjustment in AWC of only one category $(50 \mathrm{~mm})$ or less. Although these results do not constitute a rigorous test of the model, they indicate that the grass component of FORYLD provides reasonable estimates of anticipated dry matter yields of crested and intermediate wheatgrasses in western Canada.

\section{SUMMARY AND CONCLUSIONS}

The modified FAO model has been successfully used to estimate potential and anticipated dry matter yields of alfalfa and of several grass species grown in Canada. The model does not distinguish between grass species, $1 . e$. the estimated yields represent those for the species best adapted to a particular region whether that be timothy, bromegrass or crested/intermediate wheatgrass. Subroutines which estimate growth periods and cutting schedules of alfalfa and grasses were developed since these are of crucial importance to the model; yields are often 
Table 9. Comparison between observed and estimated average anticipated dry matter yield ( $B_{y a}$ ) for crested wheatgrass.

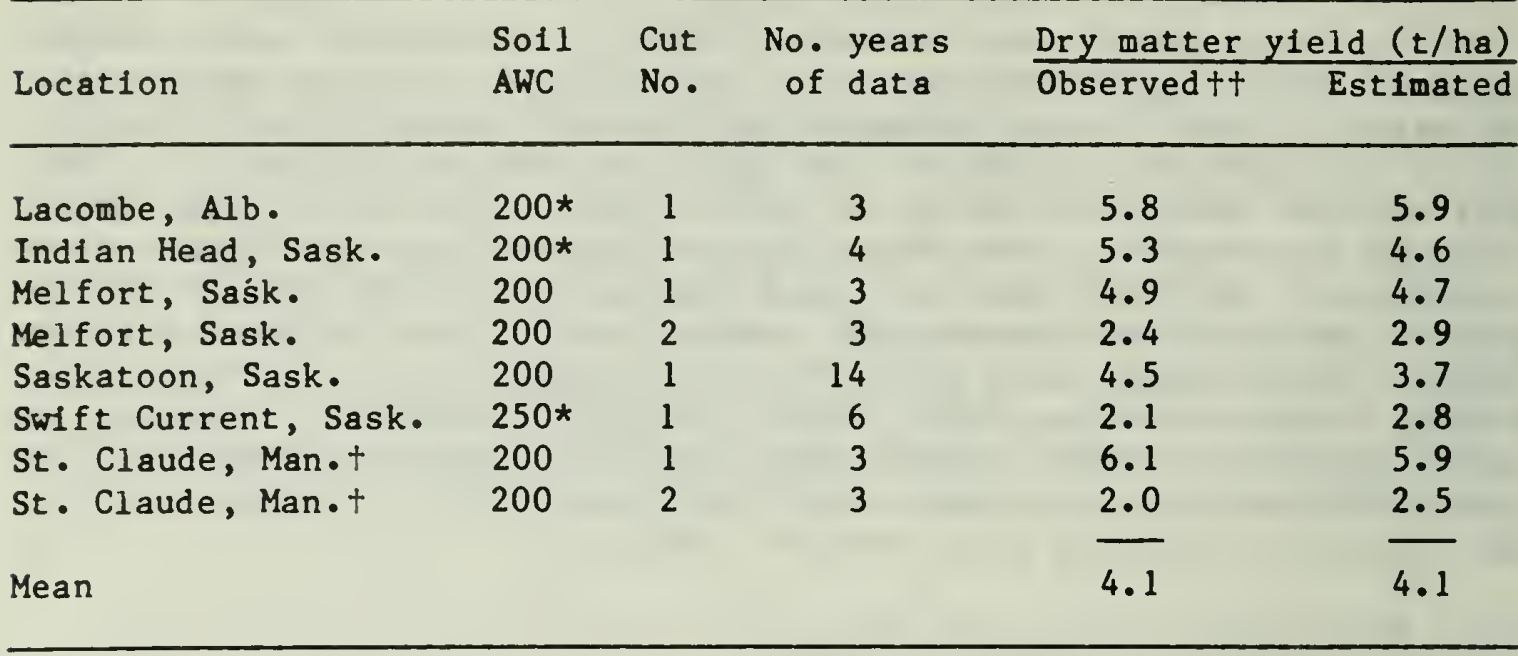

+ Climatic data from Deerwood, Man., was used to estimate yield.

t+ Average may include data from more than one trial in each year.

* Soll AWC's based on soll particle size information; all others are assumed values.

Table 10. Comparison between observed and estimated average anticipated dry matter yield ( ${ }_{y a}$ ) for intermediate wheatgrasses.

\begin{tabular}{|c|c|c|c|c|c|}
\hline Location & $\begin{array}{l}\text { So11 } \\
\text { AWC }\end{array}$ & $\begin{array}{l}\text { Cut } \\
\text { No. }\end{array}$ & $\begin{array}{c}\text { No. years } \\
\text { of data }\end{array}$ & $\frac{\text { Dry matter }}{\text { Observed }+t}$ & $\frac{\text { eld (t/ha) }}{\text { Estimated }}$ \\
\hline Beaverlodge, AIb. & 200 & 1 & 8 & 5.1 & 6.0 \\
\hline Beaverlodge, Alb. & 200 & 2 & 6 & 2.1 & 3.8 \\
\hline Lacombe, AIb. & $200 *$ & 1 & 4 & 6.3 & 5.9 \\
\hline Lacombe, Alb. & $200 *$ & 2 & 4 & 3.8 & 3.7 \\
\hline Lethbridge, Alb. & 200 & 1 & 8 & 4.3 & $4 \cdot 3$ \\
\hline Lethbridge, Alb. & 200 & 2 & 2 & 2.3 & 1.5 \\
\hline Indian Head, Sask. & $200 *$ & 1 & 12 & 4.4 & 4.6 \\
\hline Melfort, Sask. & 200 & 1 & 6 & 5.5 & 4.7 \\
\hline Saskatoon, Sask. & $250 *$ & 1 & 9 & 4.2 & 3.7 \\
\hline Swift Current, Sask. & $200 *$ & 1 & 11 & 2.4 & 2.8 \\
\hline Swift Current, Sask. & $200 *$ & 2 & 4 & 0.5 & 1.2 \\
\hline Mean & & 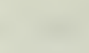 & 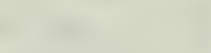 & 3.7 & 3.8 \\
\hline
\end{tabular}

t+ Average may include data from more than one trial in each year.

* Soll AWC's based on soll particle size information; all others are assumed values. 
heavily dependent on the number of cuts that can be taken. Other modifications of the FAO model included: (i) adjustment of the maximum photosynthetic rate versus temperature curve, (ii) change in the method used to calculate leaf area index and (iii) a change in the method used to determine the moisture stress factor which is used to derive anticipated yields from potential (constraint-free) yields.

Precise validation of a model such as FORYLD which computes average yields from climatic normals data is not possible due to the difficulty in obtaining suitable long-term observed yields from various locations. Nevertheless, results of validation presented here suggest that model estimates are generally within $\pm 1 t /$ ha of observed values, although individual locations may vary by as much as $\pm 2 t /$ ha. Larger yield differences between the model estimates and average yields observed in the field at some locations are likely due to management factor, stand persistence and/or overwintering damage. These factors could not be accounted for in the present model.

The yield estimates generated when FORYLD is applied to the appropriate climate data on a geographic basis should provide a useful source of information for studies in land evaluation. Estimated yields represent production levels that are attainable under irrigated (potential yield) and rainfed (anticipated yield) conditions the first few years after establishment under optimum management levels and with no winterkill.

In recent years, increased emphasis has been placed on determining crop production risk as it relates to variability in yields over time for land evaluation (Dumanski and Kirkwood, 1988). However, since FORYLD does not estimate yields on an annual basis, the risk factor in forage production cannot be assessed using this model. New modelling efforts are underway which will develop the capability of estimating forage yields on annual basis and thereby provide the required risk data. Meanwhile, estimates from FORYLD will provide a base of information which will help in assessing land suitability for forages and the potential effects of irrigation on yields. The model could also be a useful tool in evaluating the potential impact of climatic change scenarios on forage yields in Canada. 


\section{REFERENCES}

Allard, H.A. and Evans, M.W. 1941. Growth and flowering of some tame and wild grasses in response to different photoperiods. J. Agric. Res. 62:193-228.

Atlantic Committee on Crops, 1982. Forage evaluators reports. Distributed by: Dept. Plant Science, Nova Scotia Agric. College, Truro, N.S. 60pp.

Bootsma, A. 1984. Forage crop maturity zonation in the Atlantic region using growing degree-days. Can. J. Plant Sc1. 64:329-338.

Bootsma, A. and Suzuk1, M. 1985. Critical autumn harvest period for alfalfa in the Atlantic region based on growing degree-days. Can. J. Plant Sc1. 65:573-580.

Carter, P.R. and Sheaffer, C.C. 1983. Alfalfa response to soll water deficits. I. Growth, forage quality, yleld, water use, and water-use efficiency. Crop Science. 23:669-675.

Chapman, L.J. and Brown, D.M. 1966. The Climates of Canada for Agriculture. Canada Land Inventory Report No. 3, Revised 1978, Environment Canada, Land Directorate, Ottawa. $24 \mathrm{pp}$.

Clayton, J.S., Ehrlich, W.A., Cann, D.B., Day, J.H. and Marshall, I.B. 1977. Solls of Canada, Vols 1 and 2. Research Branch, Canada Dept. of Agriculture, Ottawa. 239pp.

DeJong, R. and Shields, J.A. 1988. Avallable water-holding capacity maps of Alberta, Saskatchewan and Manitoba. Can. J. So1l Sc1. 68:157-163.

DeRuiter, J.M. and Taylor, A.0. 1979. Annual cool-season legumes for forage III. Effects of temperature photoperiod and vernalisation on flowering. N. Z. J. Exp' tal Agric. 7:153-156.

DeW1t, C.T. 1965. Photosynthesis of leaf canopies. Agric. Res. Rep. 663. Centre Agric. Publ1c. Docum., Wageningen, 57pp.

Doorenbos, J. and Kassam, A.H. 1979. Yleld response to water. F.A.O. Irrigation and Drainage Paper 33, FAO, Rome. 193pp.

Dumansk1, J. and Stewart, R.B. 1983. Crop production potentials for 1 and evaluation in Canada. Agric. Canada, Res. Branch, Land Resource Research Inst1tute. Contribution 1983-13E. 80pp.

Dumansk1, J. and Kirkwood, V., edit. 1988. Crop production risks in the Canadian prairie region in relation to climate and land resources. Agriculture Canada, Research Branch, Tech. Bull. 1988-5E. 144pp.

Evans, M.W. and Allard, H.A. 1934. Relation of length of day to the growth of timothy. J. Agric. Res. 48:571-586. 
Evans, M.W. and Wilsie, C.P. 1946. Flowering of bromegrass, Bromus inermis, in the greenhouse as influenced by length of day, temperature, and level of fertility. J. Amer. Soc. Agron. 38: 923-932.

Expert Committee on Forage Crops. 1983. Uniform varlety tests of forage crops, contributed by research workers in western Canada (1983). Printed by Agriculture Canada, Research Branch. 170pp.

FAO. 1978. Report on the Agro-ecological zones project, Vol. 1. Methodology and results for Africa. World Soll Resources Report 48, FAO, Rome. 158pp.

Fisheries and Environment Canada. 1978. Hydrological Atlas of Canada. Map 10, Dates of formation and loss of snow cover. Ministry of Supply and Services Canada, Ottawa, Ont., Cat. No. En 37-26/1978.

Fulkerson, R.S. 1970. Location and fall harvest effects in Ontario on food reserve storage in alfalfa (Medicago sativa L.). In: Proc. $X I$ Int. Grassland Congress, Univ. of Queensland Press, Queensland, Australia. pp. 555-559.

Gasser, H. and Lachance, L. 1969. Effect of dates of cutting on dry matter production and chemical content of alfalfa and birdsfoot trefoil. Can. J. Plant Sc1. 49:339-349.

Harcourt, D.G. 1984. Heat units for alfalfa in southern Ontario. Agric. Canada, Ottawa, Canadex 121.10. 2pp.

Hunt, L.A., Moore, C.E. and Winch, J.E. 1970. Light attenuation coefficient and productivity in Vernal alfalfa. Can. J. Plant Sci. $50: 469-474$.

Irvine, R.B. and McElgunn, J.D. 1982. Effects of eight three-cut harvesting schedules on production of alfalfa forage under irrigation in southwestern Saskatchewan. Can. J. Plant Sci. 62:107-110.

Kilcher, M.R. and Heinrichs, D.H. 1974. Interpretive difficulties with erratic data from perennial forage crops grown in a semiarid region. Can. J. Plant Sci. 54:457-462.

Kirkwood, V., Dumanski, J., Bootsma, A., Stewart, R.B. and Muma, R. 1989. The land potential data base for. Canada, User's handbook. Research Branch, Agric. Canada, Tech. Bull. 1983-4E. 53pp.

Ludwig, R.A., Barrales, H.G. and Steppler, H. 1953. Studies on the effect of light on the growth and development of red clover. Can. J. Agric. Sci. 33:274-287.

Lutwick, L.E. and Smith, A.D. 1977. Yield and composition of alfalfa and crested wheatgrass, grown singly and in mixture, as affected by $\mathrm{N}$ and $\mathrm{P}$ fertilizers. Can. J. Plant Sci. 57:1077-1083. 
McBride, R.A. and Brown, D.M. 1984. A study of crop modeling alternatives for the hay and pasture insurance plan in Ontario. Report prepared for Crop Insurance Commission of Ontario, Toronto, Vol. 1 and 2. 166pp.

Ontario Forage Crops Committee, 1968. Forage Crops Investigations Ontario. Report on Field Trials of Varieties and Mixtures. Unpub1. Report.

Stewart, R.B. 1983. Modelling methodology for assessing crop production potentials in Canada. Agric. Canada, Research Branch, Publ. 1983-12E, Ottawa, Ont. 29pp.

Stout, D.G. 1986. The critical fall harvest period for alfalfa in interior British Columbia. Can. J. Plant Sc1. 66:565-578.

Woolley, D.G. and Wilsie, C.P. 1961. Cold unit accumulation and cold hardiness of alfalfa. Crop Sc1. 1:165-167. 


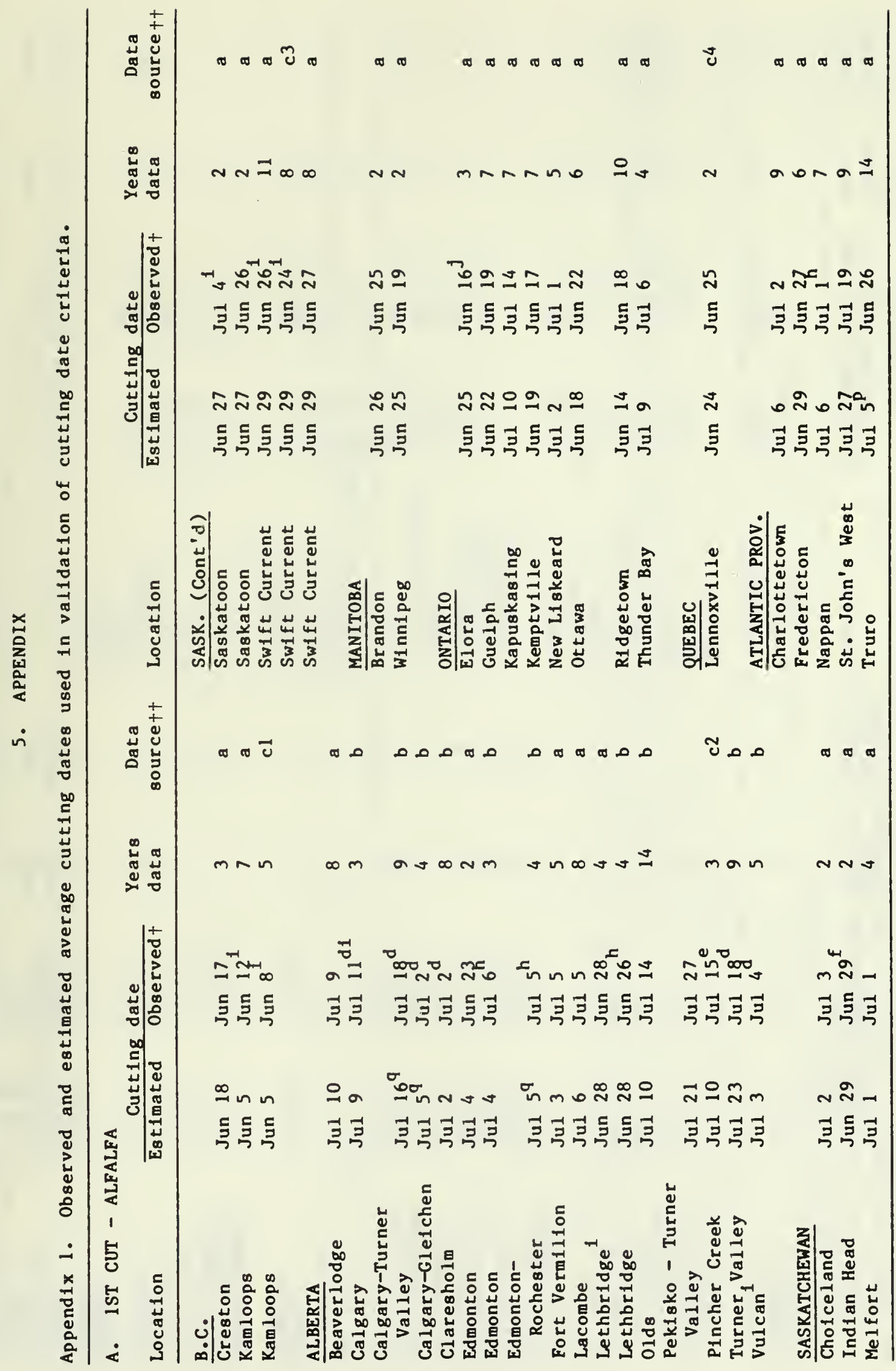




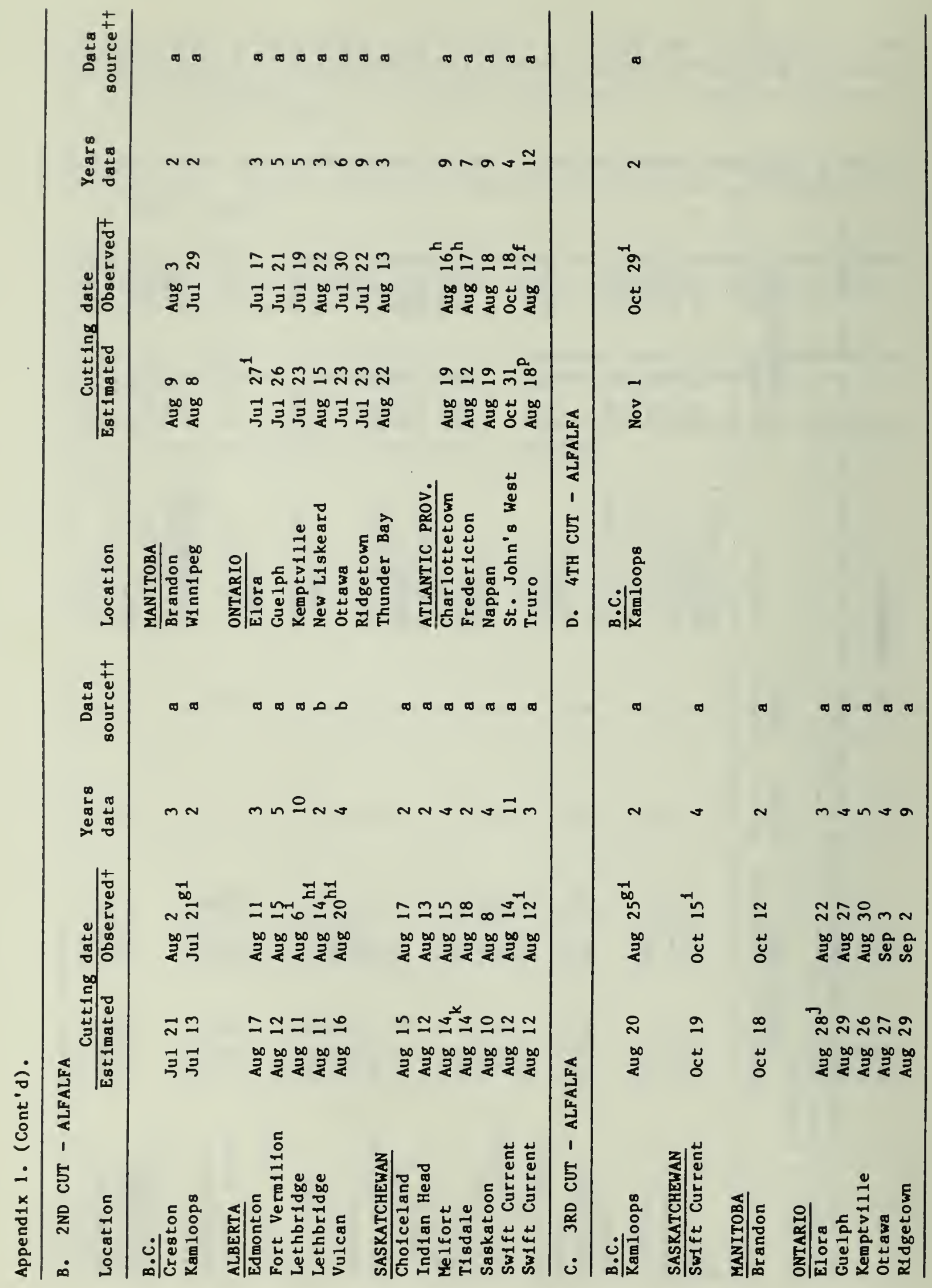




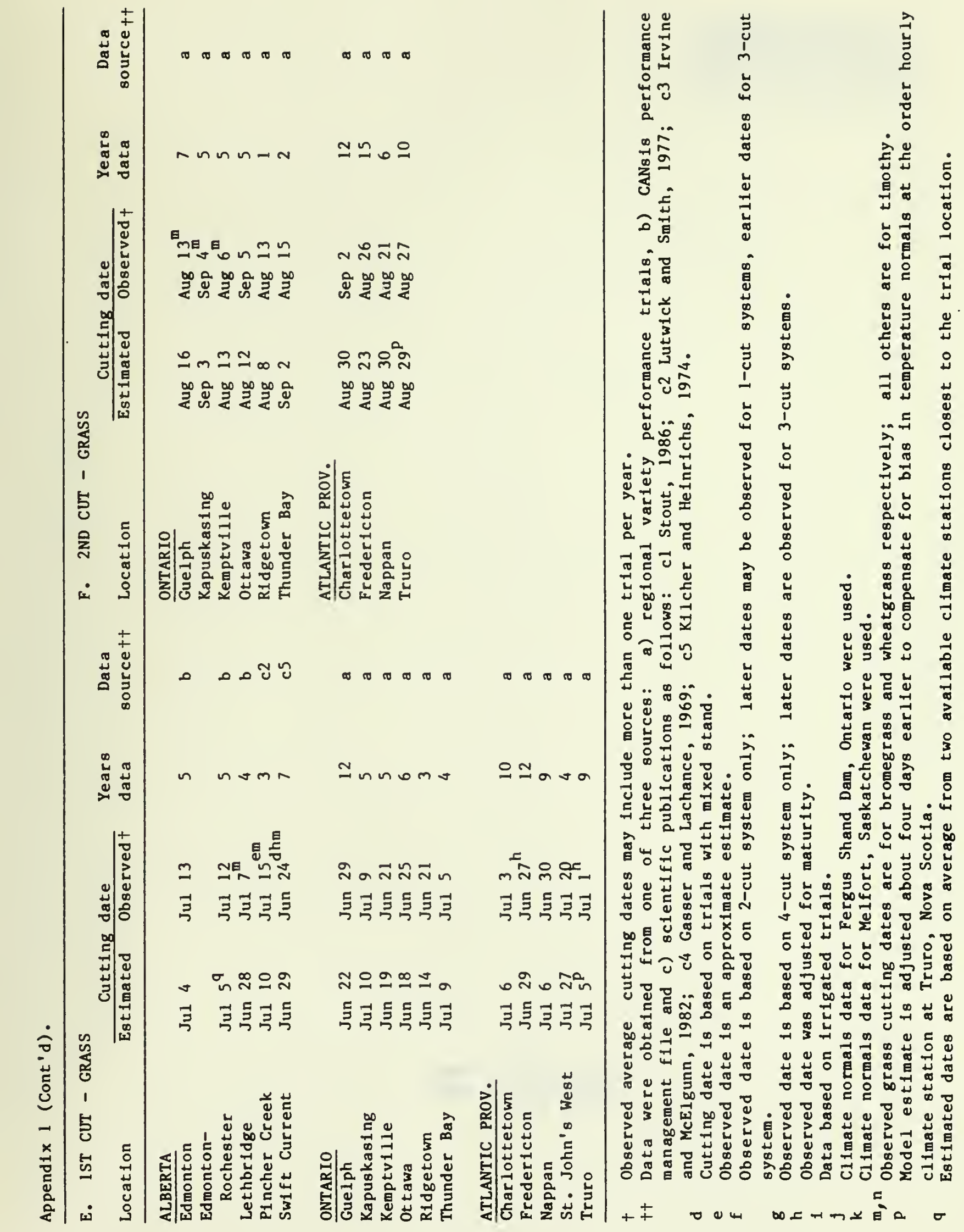




$$
\begin{aligned}
& \text { Recycled } \\
& \text { Paper }
\end{aligned}
$$


LIBRARY/BIBLIOTHEOUE

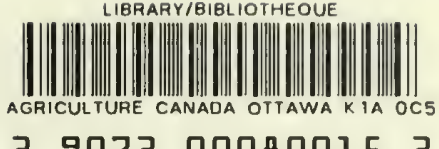

3 9073000800153 
